\title{
Agriculture Sustainability, Inclusive Growth, and Development Assistance: Insights from Tanzania
}

\author{
Emmanuel Tumusiime ${ }^{1} \&$ Edmund Matotay $^{2}$ \\ ${ }^{1}$ Policy and Campaigns Department, Oxfam America, Washington, DC, USA \\ ${ }^{2}$ Program Department, Society for International Development, Dar es Salaam, Tanzania \\ Correspondence: Emmanuel Tumusiime, Policy and Campaigns Department, Oxfam America, Washington, DC, \\ $110015^{\text {th }}$ St., NW, Suite 600, USA. Tel: 1-202-777-2928. E-mail: etumusiime@oxfamamerica.org
}

Received: June 20, 2014 Accepted: June 27, 2014 Online Published: July 31, 2014

doi: $10.5539 /$ jsd.v7n4p181

URL: http://dx.doi.org/10.5539/jsd.v7n4p181

\begin{abstract}
Aid for agriculture development in sub Saharan Africa has increased in recent years, but little is known about which farmers are participating in the interventions, the production structures employed, and the foreseeable consequence on food security and agricultural development. This research draws insights from two projects in Tanzania funded by the United States under its Feed the Future initiative. The research examined the categories of farmers participating, production structure employed, and the implications for sustainable and inclusive food security and agricultural development. The research reveals that significant results of sustainable production can be found at individual level, but only a limited number of farmers with endowment of suitable land with access to water, and credit and some level of organization are participating. The UN rapporteur on the Right to Food has called for increasing food production where the poor and hungry live; we argue that current investment approaches oriented to increasing production, fail to adequately address the local specificity of hunger. As a result, substantial increases in aid inflows over the recent years may have limited effect on reducing the numbers of the hungry. The challenge to stakeholders is to spread the technologies to many more smallholder producers, particularly targeting the poor more precisely.
\end{abstract}

Keywords: agriculture, development, inclusive, sustainability, Tanzania

\section{Introduction}

Concerns about insufficient progress toward the Millennium Development Goals, especially in sub Saharan Africa, have prompted a renewed interest in the agriculture sector. And in the aftermath of the 2007 and 2008 sharp rise in food prices, a number of global initiatives emerged seeking to bolster agriculture in Sub Saharan Africa. These include, for example, the G8 L'Aquila Food Security Initiative, the Global Agriculture and Food Security Program, and the World Bank's Global Food Crisis Response Program. Funding has also come from philanthropic donors (such as the Gates Foundation) and private sector companies under frameworks such as the Grow Africa, and the New Alliance for Food Security and Nutrition.

With increased funding, two main criteria are identified as particularly important for an agricultural-led (based) development: inclusive investments in the sense of involving the majority smallholders, and sustainability (Djurfeldt, 2012; Diao, Hazell, \& Thurlow, 2010; World Bank, 2007). The former is borne out of a large literature showing strong linkages and poverty reduction effects of growth in the smallholder agriculture sector (De Janvry \& Sadoulet, 2009; Diao, Hazell, \& Thurlow, 2010), while the latter, is in response to the challenges faced by the agriculture sector, including in particular ecological and economic sustainability, and adapting to climate change (Montpellier Panel, 2013; World Bank, 2007). Indeed, several recent studies, for instance Pretty, Camilla, \& Stella (2011) and Godfray et al. (2010) have reaffirmed the goal of current agriculture development as not just to maximize productivity, but to optimize it over environmental, socio-equity and economic outcomes.

However, in the context of recent agriculture development initiatives, although most commit, at least in general terms, to target smallholder farmers, little is known thus far about who is participating and the production structures in respect to the environment and socio-economic sustainability. Who is participating is particularly important because some assessment of aid to agriculture in developing countries (Riddell, 2007; IEG, 2007), and 
more recently, shift in direction of agrarian change towards commercial and large-scale agriculture (Djurfeldt, 2013; Deininger et al., 2010), suggest that participation is likely to be available to only a few producers well-endowed to quickly 'step up' to formal markets. This is of particular concern in the case of sub-Saharan Africa when contrasted with the fact that nearly 27 percent of the population is classified as hungry (FAO, 2012) despite considerable growth in agriculture and in national economies over the last decade.

This research examines the specific case of two projects in Tanzania funded by the United States government (USG) under its Feed the Future (FtF) initiative, an outgrowth of the G8 L'Aquila commitments. Specifically, the study examines which farmers are participating and production structures, and the implications for food security and agricultural development. The projects, one focused on increasing the productivity of rice and maize, and the other on horticulture, are of particular interest because they encompass subsectors where most smallholder farmers in Tanzania are involved directly. Thus, the kind of improvements promoted in these subsectors has implications on sustainable and inclusive food security and economic development. More broadly, lesson drawn from a major donor initiative could inform other agriculture development initiatives and projects not only in Tanzania but also in other countries.

Tanzania provides a particularly interesting case for this study. The government of the United Republic of Tanzania (URT) has placed growth in the smallholder agriculture sector at the center of its economic growth strategy; for instance, it's Kilimo Kwanza (Agriculture First) initiative which emphasis commercialization of family farming (URT, 2009). At the same time, the country already receives unprecedented aid flows with agriculture one of the key sectors promoted to donors (OECD, 2013). The FtF funding, for example, constitute the second largest contribution to Tanzania's agriculture sector medium- term development plan and the largest contribution from a single donor, with $\$ 350$ million pledged over a five year period: 2010-2015 (URT, 2011). Although Tanzania's agriculture sector is estimated to have grown over the last decade, studies show that this growth has been concentrated in few crops, especially for export such as cane sugar, tea and tobacco and among large-scale farmers (Pauw \& Thurlow, 2011). The key issue now appears to be how to better target interventions to involve majority smallholder farmers and to sustainably increase production.

Increased aid flows to agriculture (and also to other sectors) have been accompanied by the rise of the development effectiveness movement which has called for more impact assessments. In response to this demand, quantitative techniques based on random choice of project participants and panel data have risen as 'gold standard' for estimating impacts of projects and forming firm conclusions about what works. However, this exclusive outlook threatens to bar important evidence from the dialog especially non-material impacts and narrative on social differences, which are important for capturing dimensions of poverty that are harder to measure (Garbarino \& Holland, 2009) or on which data is incomplete or limited (Riddell, 2013). Yet, there is also need for information about whether interventions are on the right track to reach ambitious goals as well as important for obtaining feedback from communities. This research uses qualitative methods. It contributes to the debate about agriculture sustainability and inclusive growth in the context of current processes of agrarian reform and recent food security initiatives. Based on the cases examined, the research reveals that significant results of sustainable production can be found at individual level, but only a limited number of farmers with endowment of suitable land with access to water, and credit and some level of organization are participating. The challenge to stakeholders is to spread the technologies to many more smallholder producers, particularly targeting the poor more precisely. The UN rapporteur on the Right to Food, Olivier De Schutter (2014), has called for increases in food production where the poor and hungry live; this research argues that current investment approaches oriented to increasing production, fail to adequately address the local specificity of hunger.

\section{Background: Food Security and Agriculture Development in Tanzania}

\subsection{Food Security in Tanzania}

Tanzania, like many other countries in sub Saharan Africa, is considered well-endowed with significant water and land resource suitable for agriculture. However, a long standing challenging faced by the government and its development partners is how to develop effective policies and programs or projects that effectively tap this potential to cause broad-based economic prosperity, especially among smallholder producers in rural areas (OECD 2013). However, it should be noted that Tanzania has maintained a high level of self-sufficiency in food, which has ranged between the high 80 percent to low 90 percent over the last decade (WFP, 2013). Nonetheless, food security is uncertain in many households. For instance, in October 2012, the International Food Policy Research Institute [IFPRI] and its partners in the Global Hunger Index project, released a report in which 
Tanzania is ranked $54^{\text {th }}$ out of 79 countries, with a score of 19.3 , indicating 'serious' food insecurity (IFPRI, Concern Worldwide \& Welthungerhilfe, 2012).

Food insecurity is localized, mostly in food deficit districts and households without the ability to produce enough, or where economic opportunities are too limited to enable food access through the market. According to the WFP (2013), about 40 percent of Tanzanians live in food deficit areas, which mostly are semi-arid areas in the far north and south with less potential to produce sufficient cereals and have poor infrastructure to enable access from other regions. This exemplifies assertions by De Schutter (2014) and researchers such as (Kannan, 2014) that hunger is not much linked to the quantity of food produced but to access and poverty. It is evident therefore that policies and programs geared towards supporting sustainable production methods that are more accessible and viable for poor smallholder farmers may help to better secure access to food of the rural poor.

\subsection{Agriculture Development in Tanzania}

Attempts to address the challenge of poor performance of agriculture in Tanzania have resulted in a series of policies and investment frameworks in the recent past. The government launched the Agricultural Sector Development Program (ASDP), in 2006, as a medium-term (2006-2013) agriculture sector development plan, with the principal objective of enabling farmers to have better access to and use of agricultural technologies, and to promote private investment. When ASDP did not lead to the expected results, a new initiative, the Kilimo Kwanza (Agriculture First), was launched in 2009 to provide a new push for ASDP. Around the same time, in 2010, the government adopted the Comprehensive Africa Agriculture Development Program (CAADP) compact. This was followed in 2011 by the launch of the Tanzania Agriculture and Food Security Investment Plan (TAFSIP) to operationalize the CAADP compact (URT, 2011). In practical terms, however, TAFSIP is essentially an enhanced version of the ASDP, while the Kilimo Kwanza remains generally the guiding framework for agriculture investments in Tanzania.

The Kilimo Kwanza initiative's vision is to cause transformation of small-scale agriculture into commercial small-scale farming on the model of the Green Revolution through public-private partnerships (PPP), as well as to promote large-scale commercial farming (URT, 2009). With large-scale agriculture, it is hoped that smallholder farmers will benefit by being involved in the supply chain, for example as out growers or through contract farming. As part of the implementation of the Kilimo Kwanza initiative, the government of Tanzania identified a core area, in 2010, the Southern Agricultural Growth Corridor of Tanzania (SAGCOT), as a focus of public private-sector partnerships. Furthermore, in September 2012, the government of Tanzania committed to the New Alliance for Food Security and Nutrition (NAFSN), a public private partnership (PPP) that is aimed to bring together resources of G8 donors, governments in focus countries, and agribusiness companies (both local and multinational corporations). The NAFSN dovetails particularly well with the Kilimo Kwanza's goal of attracting greater private investments in agriculture. The Kilimo Kwanza has already won substantial support from donors, including the World Bank and the US through Feed the Future, and 'good-will' from international multi-stakeholder agriculture investment platforms such as Grow Africa and the World Economic Forum.

Some none governmental organizations (NGOs), scholars and representative organizations of small-scale farmers have voiced concern, however, that small-scale farmers will certainly not benefit, and that the real impetus of the Kilimo Kwanza is to promote large scale, export-oriented farming, particularly around the SAGCOT area where a major emphasis has been placed on large-scale commercial farming. Their concerns are not without basis, however. Since the surge of global food prices in 2007/2008, many governments in sub-Saharan Africa have become receptive to the idea of transferring large pieces of land to private agribusiness companies. According to pillar five of the Kilimo Kwanza initiative, the Village Land Act No. 5 of 1999 will be amended to "facilitate equitable access to village land for Kilimo Kwanza investments" (URT, 2009).

The SAGCOT area has a particular appeal among donors and investors because it is seen as a high-potential agriculture area (in terms of accessibility, water resources, soil fertility and climatic conditions); yet appear inefficiently utilized and therefore good for investment to rapidly boost production. This is generally what has shaped the government's interest to offer land to investors who (claim to) have capital and skills to efficiently utilize the land. By offering high-potential agricultural areas for investment, the government hopes that greater agricultural output and employment will result, which consequently will lead to lower food prices to the benefit of the poor, including those in less-productive (or favored) areas. Some analysts have also argued that rapidly increasing production in high-potential areas is the surest way to guarantee food for rapidly growing urban populations. This is contrary to calls from the UN rapporteur on the Right to Food (De Schutter 2014), and some scholars (Kannan, 2014) and as well as some non-governmental organizations for greater investments in areas where the hungry live. 
Over three-quarters of the FtF investments in Tanzania are also concentrated in the SAGCOT (USG, 2011). According to the investment framework in Tanzania (USG, 2011), FtF covers three components: (i) improving productivity and market access, (ii) improving nutrition, and (iii) learning and policy changes. The primary focus of this research is on the first component. The goal of this particular component is to be accomplished by improving the productivity and access to markets of small-scale producers, of which the two projects explored in this study constitute the core specific activities. Essentially, the planned change outcome of the two projects is to reorient small-scale farmers to engage in farming as a business, similar to the vision of Kilimo Kwanza. The rice and maize project is implemented by ACDI/VOCA, and is commonly called NAFAKA, and the horticulture project is implemented by Fintrac, and is commonly called Tanzania Agricultural Productivity Program (TAPP). The two projects are five year interventions and had been 3 years in operation at the time of data collection. The next sections examine the prospects of the interventions to achieve the goal of inclusive and sustainable outcomes.

\section{Research Methods}

\subsection{Data}

To provide insights on the questions raised in this paper in relation to FtF, we employ a qualitative methodological approach, which is appropriate for enabling understanding of phenomena and experiences (Silverman, 2013), and a recognized tool for project implementation and process analysis (Garbarino \& Holland, 2009). The approach involved: reviewing literature, surveying key stakeholders to gain their perceptions, and field visits to inform the discussion. Key stakeholders identified for this research include farmers benefitting from the FtF projects, project implementers, USAID staff, relevant local government staff, and informed stakeholders mainly from the NGO community. Data collection involved individual interviews with stakeholders (other than farmers) and focus group interviews with farmers' groups benefiting from the NAFAKA and TAPP. The interviews were guided by a semi-structured questionnaire to obtain qualitative information about what categories of farmers are targeted and how beneficiaries are selected, the real and perceptible impacts of interventions on livelihoods, adaptability and sustainability of innovations, and involvement of local institutions. Some questions to gather basic numerical data were also asked, the aim of which was to provide some indicative data. Preparation for the field work involved meetings with USAID staff and lead project implementers. The data was collected in two periods: February-March 2013, and in May-Early July 2013.

Farmers' groups sampled were purposively selected from a list provided by project implementers, and farmers included in focus group interviews were mobilized by group leaders. This means that rural women and men who were not involved with the FtF projects-TAPP and NAFAKA- were not interviewed by way of comparison or control. Instead comparisons, where made, are based on the counterfactual self-estimation principle, which recognizes that project participants are capable of making hypothetical judgments about the state they would be in had they not participated in the intervention (Mueller, Gaus \& Rech, 2014; Mueller \& Gaus, 2014). Also, no attempt was made to create a statistically representative sample of a particular population subset; instead a deliberate effort was made within the qualitative approach to interview a broad cross-section of stakeholders, and particularly women farmers. The analysis draws from interviews with 27 individual stakeholders (16 men and 8 women) and 19 focus group interviews comprising of 152 participants (69 men and 83 women); four of the focus group interviews were exclusively with female farmers, five were with men and 10 were mixed. The groups ranged in size from 5-10 participants.

The field work was carried out in Ifakara, Mvomero, and Kongwa districts in the SAGCOT area (the primary target area for NAFAKA), and around the slopes of Mt. Meru (Arusha and Arumeru districts), slopes of Mt. Kilimanjaro (Hai district) and Tanga region (Lushoto district)-areas of intervention for TAPP. The number of focus group interviews conducted is not balanced across the districts or projects; focus group interviews in a given area and per crop depended on the level of $\mathrm{FtF}$ interventions, and consideration to ensure a mix of high and low performing farmer groups. Of the 19 focus group interviews, 42 percent were horticulture farmers; and 32 percent and 26 percent maize and rice farmers, respectively.

\subsection{Analytic Framework}

Sustainable and inclusive agriculture-based development is multidimensional and a function of a series of interrelated factors. Conceptually, however, sustainable agriculture encompasses the productive, ecological, and socio-economic factors functioning in synergy (Montpellier Panel, 2013; Pretty, Camilla, \& Stella, 2011; Godfray et al., 2010). In practice, it implies utilizing existing land to produce higher yields and net incomes while using environment friendly practices within enabling environment created by social and institutional processes. Inclusiveness, on the other hand, is concerned with broader participation, in that development 
activities are an opportunity for all, including in particular the economically and socially marginalized groups (De Schutter, 2014). Participation can be thought of along a continuum of increasing degree of engagementfrom nominal or passive level (for instance being informed about decisions ex-post) to actively undertaking activities or initiatives, and to empowerment level in which participants have a voice and agency (Bretty, 2003). With respect to a development project, active participation is often considered the minimum desired level and is widely understood in practice to imply that beneficiaries and local institutions are actively consulted and involved in identifying needs, implementing, monitoring and in evaluation of project activities.

The concepts of sustainability and inclusivity are not necessarily new in development literature, but have rarely been applied as a common framework to analyze solutions to hunger problems in developing countries. To guide analysis and discussion of field data, we propose a set of key success indicators from the common framework as shown in figure 1. From the aid effectiveness point of view, these success indicators are central to the short-term success and long-term viability of FtF interventions. It is therefore of particular interest to observe practical instances how they manifest.

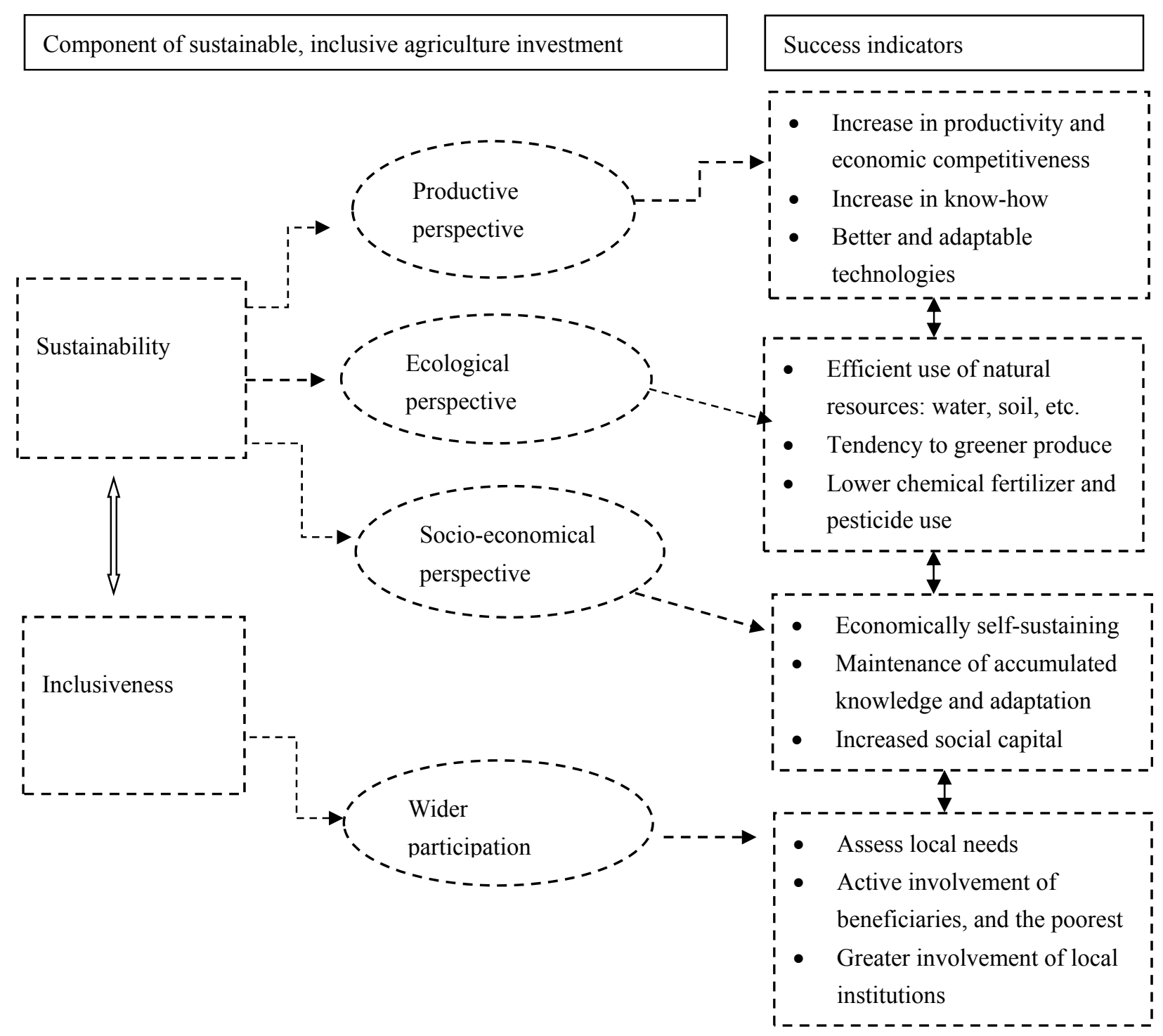

Figure 1. Empirical model for sustainable, inclusive agricultural development at the farm level

\section{Field Results and Discussion}

Field data and observations are presented and discussed along the four perspectives presented in the analytic framework. 


\subsection{Participation}

In this section, we discuss which categories of farmers are receiving direct support with the underlying hypotheses that projects are targeting the poor, but not the poorest in particular communities, and that interventions are relevant to the needs of the people, but not adapted to local conditions.

Interviews revealed that though there is no asset or minimum acreage requirement to participation in project activities, being in an organized group (for instance, a cooperatives or farmer association) is a primary criterion used to identify prospective beneficiaries. The groups are considered effective service delivery and receiving systems as well as instruments for mobilizing local participation. Most of the farmer groups predate FtF interventions, and are encouraged by government policy as the most appropriate systems to increase competitiveness of family farming through pooling resources in order to improve the position in the agri-food chain, access to finance and technology.

More generally, participation, especially for rice and horticulture crops, is conditioned by access to suitable land with access to water, and capital. For maize, which is mostly produced under the rain-fed system, land is not a binding constraint to participation. This is partly because Tanzania as a whole is less densely populated, at least compared to its neighbors, and only 40 percent of the total land area is under agricultural use (OECD, 2013). Land rental costs are generally low. However, most of the rice and vegetable growers interviewed irrigate their fields, and that costly according to farmers interviewed. For instance, a farmer who grows cabbages, onions, and tomatoes indicated that it costs 9 to 10 liters of gasoline weekly to irrigate a fifth of an acre. Rice farmers of UWAWAKUDA cooperative voiced a similar concern over water and the cost of pumping it to the fields.

Many potential participants face capital constraints to enable them to adopt the farming technologies promoted under the two FtF projects. This is also true for some farmers who have received knowledge from FtF through demonstrations, but lack capital to actually practice what they have seen or learned. In reality, the problem of affordability is more due to farmers' credit constraints and risk aversion than to the farming technologies being expensive. Typically, farmers apply very little or no fertilizer (Benson, Kirama, \& Selejio, 2012), sow recycled seed and rely on family labor in their traditional farming systems. Thus, and effectively, even farming technology requiring modest usage of purchased inputs is, in the view of many farmers, costly. Interventions need to critically consider increasing access to fair and flexible credit as a complimentary activity.

Correspondingly, the question of whether or not the interventions reach the very poor smallholder farmers generated opinions that are divided. Representatives of project implementers and staff of USAID assert that the interventions certainly reach the economically vulnerable smallholder farmers, including women farmers. This is also a stated strategic objective of FtF (USG, 2011). Our data is limited from which to unambiguously conclude whether or not the two projects reach the poorest of the poor within particular communities. However, and as discussed previously, field interviews and observations suggest that participation is conditioned by endowment of suitable land with water access, finance to invest, and some level of organization. The poorest not only lack resources but are also among the least organized. It is worth noting also that we did not find beneficiaries or groups in the two projects not in need of support.

The study's hypothesis that projects are relevant to the needs of local people, but not based on systematic assessment of needs was confirmed from interviews with beneficiary farmers and local government officials. Local people are involved at the implementation as beneficiaries according to responses from field interviews. Interviews revealed, however, that though no consultation with local people takes place prior to implementation, project activities are appreciated in local communities. The reason in part has to do with the public agricultural extension service which is ineffective in rural areas, and thus farmers appreciate support from projects.

Conversely, views expressed by local government officials (at the district and ward level) also suggested little awareness and ownership of FtF programs. Their views imply partnerships between the government and donors are top-down, lacking meaningful participation of local stakeholders. For instance, a Ward Agriculture Extension Officer in Lushoto district lamented: "I am surprised that agriculture experts come from the US to give agriculture advice to farmers, while ignoring us. This is not the proper way of supporting our agriculture. "Typically, agricultural development in Tanzania, as is in much of sub Saharan Africa, is decentralized to districts as implementers of programs including extension and cooperatives. Failure to effectively coordinate with the local governments inevitably undermines local institutional ownership as well as institutional strengthening, a long standing challenging of development aid (Riddell, 2013; IEG, 2007). Overall, however, evidence of coordination and alignment of interventions with national development frameworks exist, for example with Kilimo Kwanza and TAFSIP, but not with local government stakeholders where interventions appear to replace rather than complement their roles in service delivery. 


\subsection{Sustainability: Productive and Ecological Perspective}

For smallholder farmers employing family labor, a representative and direct indicator of productivity is yield (per hectare). Field interviews revealed that interventions have facilitated the introduction or adaptation of improved farming techniques, especially with regard to higher yielding varieties and the economy of external inputs and natural resources that are having a positive impact on yields. Beneficiary farmers interviewed in both projects reported yield increases of between 100 to 150 percent compared to seasons before FtF projects. The yield improvements demonstrate that the knowledge gap of production for these crops is being solved. The yield gains also confirm the assertion that traditional farming methods practiced by the majority of farmers in Sub-Saharan Africa are sub-optimal, and huge yield gaps exist to exploit. In Tanzania, for instance, average yields of smallholder producers for staple crops is 20 to 30 percent less than the potential yields with the deficit often attributed largely to poor farming techniques and low levels of application of external nutrients, mainly inorganic fertilizer (Benson, Kirama, \& Selejio, 2012).

The improved farming practices promoted are founded on crop intensification techniques. For horticulture crops, farmers are taught to plant the crop in raised beds, early transplanting, proper spacing, planting improved seeds, reliance on Integrated Pest Management (IPM) techniques and cultural practices (e.g. removing diseased plants and keeping the garden clean of weeds). For maize, the standard technology package involves teaching farmers to plant in rows and follow proper spacing, to use improved seeds and apply sufficient fertilizer. The maize and horticulture technology package is essentially the full suite of practices under the orthodox extension system, but are rarely applied by farmers particularly because public agricultural technology development and transfer services are ineffective or not available in rural areas. Meanwhile, for rice, the farming practice is the System of Rice Intensification (SRI), which has been praised for substantially raising yields by merely changing how the crop is established and managed in the field. With SRI, farmers are taught practices such efficient fertilizer use, early transplant to the field, and keeping the soil moist - principles founded on the physiology and patterns of rice growth (Stoop, 2011).

A consistent observation by farmers was that SRI is new and preferred technique of rice farming. Compared to conventional rice cultivation, SRI has a particular appeal. Besides increasing yield, it is credited with saving seeds and reducing usage of inorganic fertilizers. Project agronomists also contend that SRI is saving water and increasing soil organic matter on farmers' fields due to green manuring and weed incorporation, although no empirical evidence of results is provided. These benefits have also been reported in many empirical studies in India, Madagascar, and other countries on the Asian continent where SRI has become a wide-spread practice (Africare, Oxfam America, \& World Wildlife Fund, 2012; Stoop, 2011). The foregoing discussion suggests that the interventions are acting as a drive for technological, particularly empowering participating farmers with skills and knowledge of sustainable production.

From an ecological point of view, the TAPP and NAFAKA projects have tended to harness agro-ecological-friendly farming practices. For instance, high productivity under SRI and conservation farming systems have occurred with minimal or efficient use of chemical external inputs and water, consequently minimizing the footprint on the environment. Pretty, Camilla, \& Stella (2011) point out that such outcomes are characteristics of 'sustainable agriculture intensification'. Interestingly, most farmers interviewed consider environmental concerns a 'far-cry' by the elite or simply overstated. Typically, the prevalent capital constraints and market failures, constrain over application, even of optimal amounts. Noteworthy, even though the use of external inputs such as fertilizers and insecticides is gaining prominence, the agriculture system practiced in the region is not yet intensive enough and still relies on limited chemical inputs.

\subsection{Sustainability: Socio-Economic Perspectives}

The success of the agriculture-based development initiatives depends greatly on guaranteeing income levels of producers, fairly distributing productive resources between economic and social classes, and increasing participation of the wider segment of the community. In the case of the two projects, intensification is allowing greater yield per unit area, and with efficient use of inputs; beneficiary small-scale producers reported improvements in their farm incomes. Farmers cited these outcomes as motivation to continue with the new farming practices. The drawback to these projects is that many smallholder producers are effectively excluded from participating as they are not advantaged with access to water and financing, and some level of organization. The challenge to stakeholders is to spread the technologies and effective process to many more smallholder producers.

As far as the social dimension is concerned, there is potential for increase in social capital as farmer groups have enabled more interactions, learning and networking among farmers and with other groups through field exchange 
programs. As for the adaptability of the technologies and farming practices, a good indicator is the "rate of adoption" and locals" ability to implement the technologies. While this study is limited in scope and not intended to estimate adoption rates, many groups interviewed had significant numbers of passive members. In addition, some farmer groups are not doing as well as expected because they have not gained sufficient technical knowledge or attained sufficient organizational capacity when direct support from the FtF project is terminated, or both. Interactions with farmers groups also revealed that the support they receive focuses on the technical aspects of production with no training to strengthen the groups' capacity in activities such as group organization and leadership.

A further challenge and perhaps a drawback of SRI and conservation farming is that they are labor intensive and time demanding. Our field interviews established that smallholder farmers, especially those without sufficient family labor and without capital to hire laborers, rarely follow all the guidelines of SRI and some are not adopting at all, similar to the findings of Moser \& Barrett (2003) in Madagascar. Horticulture farmers interviewed also voiced similar concerns regarding labor intensiveness; particularly that it leads to labor reallocation from other household activities and leisure to agro-ecological/conservation farming activities, consequently inhibits quality of life of farmers.

Another social effect of concern to analysts is the type of seeds promoted to farmers. Some farmers have had to grow certain varieties, for instance, SELO5 rice, even though the taste is not what they prefer for eating at home. Farmers noted they grow SELO5 for commercial purposes and buy the local variety for home consumption from the market. The use of hybrid varieties is generally widespread, often encouraged by government policy and interventions as necessary for obtaining higher yields. Some farmers noted, however, that despite appeal of early maturity and market value, hybrid seeds perform better than local seeds only with adequate fertilizer inputs and better husbandry. And civil society groups and some scholars (Miguel, 2009) opine, that although commercial varieties are good for higher yield and potentially bringing in more currency, they are making farmers dependent on uncertain markets for their seed and food security needs, and doing harm to local genetic diversity. In particular, local varieties are known to offer greater harvest security in the midst of diseases, pests, and droughts that are becoming common with the changing climate. Moreover, and as experiences with SRI have shown, local varieties can often be adapted to increase productivity.

\section{Conclusion and implications}

Investment in agriculture has increased in recent years in response to frequent global food crises and persistent poverty in rural areas in low-income countries. With the rise of the development effectiveness movement over the last decade, however, impact evaluations have become more important to provide insights about what works and or whether interventions are on the right track to reach ambitious goals, including in particular inclusive and sustainable outcomes, main challenges faced by policymakers concerned with agriculture-based development. This research examined the specific case of two projects funded under the United States Feed the Future initiative in Tanzania. The research used qualitative methods to examine the categories of farmers participating and the production structure employed, and the implications for sustainable and inclusive economic growth and food security.

The broad findings indicate that the two projects have demonstrated success in transferring horticulture, maize, and rice crop intensification farming technologies to small-scale farmers. The technologies and farming practices have raised yields of participating farmers. Through more efficient use of inputs and greater yield per unit area, beneficiaries report improved farm income. Participating farmers voice a sense of achievement and empowerment as a result of the knowledge gained through the interventions. However, perfecting and systematizing these technologies is a slow process; thus, sustained support will be critical for sustainability of results.

At the same time, not all small-scale farmers are positioned to take advantage of these programs, potentially limiting the objective of achieving inclusive agricultural growth. Investment costs for crop intensification are high for most small-scale farmers to afford. Small-scale farmers continue to face the long-standing challenges of accessing flexible and affordable credit. They find modest capital requirements unaffordable, and some are simply risk averse to invest the little capital they have. In general, smallholder producers actively participating are relatively well endowed with land that has access to water, capital to invest, and some level of organization. This suggests that the very poor and food insecure within particular communities may be missed to receive direct benefits because they not only lack productive resources but are also among the least organized and thus hard to reach through organizations. However, we also did not find beneficiaries or groups in the two projects not in 
need of support. The challenge for stakeholders is to spread the technologies to many more small-scale farmers by devising means to increase access to credit at affordable, flexible, and fair terms to support project activities.

Much more emphasis needs also to be placed on building the capacity of farmers' associations as economic empowerment units, not just as passive recipients of innovations. Leadership and group management and development training need to be made a part of the menu of project activities. Consultation with local communities should also be taken into account so that interventions find greater relevancy to local needs and ownership as well as enlisting broad based participation.

With regard to scaling up to reach more farmers or even sustainability of results, we need to be careful: given the significant resources available for donor projects and the fact that local government involvement is marginal, it remains to be seen if more farmers will adopt these technologies. Future research should seek to systematize the conditions under which such successes are likely to emerge.

\section{Acknowledgement}

Funding for field work was provided by Oxfam America, an international relief and development organization advocating for effective development programs and longer-term solutions to poverty. The views expressed in the article are the authors'. They are not endorsed by Oxfam America or necessarily reflect Oxfam America's position and policies on the subject(s) discussed in the article.

\section{References}

Africare, Oxfam America, \& World Wildlife Fund (WWF). (2010). More Rice for People, More Water for the Planet. Hyderabad, India: WWF. Retrieved from $\mathrm{http} / / /$ www.oxfamamerica.org/static/oa3/files/more-rice-for-people-more-water-for-the-planet-sri.pdf

Benson, T., Kirama, S., \& Selejio, O. (2012). The Supply of Inorganic Fertilizers to Smallholder Farmers in Tanzania: Evidence for Fertilizer Policy Development. Washington, DC: International Food Policy Research Institute. Retrieved from http://www.ifpri.org/sites/default/files/publications/ifpridp01230.pdf

Bretty, E. A. (2003). Participation and Accountability in Development Management. Journal of Development Studies, 40(2), 1-29. http://dx.doi.org/10.1080/00220380412331293747

De Janvry, A., \& Sadoulet, E. (2009). Agricultural Growth and Poverty Reduction: Additional Evidence. The World Bank Research Observer, 25(1). http://dx.doi.org/10.1093/wbro/lkp015

De Schutter, O. (2014). The Transformative Potential of the Right to Food. Retrieved from http://reliefweb.int/sites/reliefweb.int/files/resources/A_HRC_25_57_ENG.pdf

Deininger, K., Byerlee, D., Lindsay, J., Norton, A., Selod, H., \& Mercedes, S. (2010). Rising Global Interest in Farmland: Can it Yield Sustainable and Equitable Benefits? Washington, DC: World Bank.

Diao, X., Hazell, P., \& Thurlow, J. (2010). The Role of Agriculture in African Development. World Development, 38(10), 1375-1383. http://dx.doi.org/10.1016/j.worlddev.2009.06.011

Djurfeldt, A. A. (2013). African Re-Agrarianization? Accumulation or Pro-Poor Agriculture Growth? World Development, 41, 217-231.http://dx.doi.org/10.1016/j.worlddev.2012.06.013

Food and Agriculture Organization (FAO). (2012). The State of Food Insecurity in the World 2012. Rome, Italy: FAO. Retrieved from http://www.fao.org/docrep/016/i3027e/i3027e.pdf

Garbarino, S., \& Holland, J. (2009). Quantitative and Qualitative Methods in Impact Evaluation and Measuring Results. Birmingham, England: University of Birmingham. Retrieved from http://epapers.bham.ac.uk/646/1/eirs4.pdf

Godfray, C., Beddington, J. R., Crute, I. R., Haddad, L., Lawrence, D., Muir, J. F., Pretty, J., Robinson, S., Thomas, S. M., \& Toulmin, C. (2010). Food Security: The Challenge of Feeding 9 Billion People. Science, 327, 812-818. http://dx.doi.org/10.1126/science.1185383

Independent Evaluation Group (IEG). (2007). World Bank Assistance to Agriculture in Sub-Saharan Africa: An IEG Review. Washington, DC: World Bank. Retrieved from https://openknowledge.worldbank.org/handle/10986/6907

International Food Policy Research Institute, Concern Worldwide, \& Welthungerhilfe. (2012). Global Hunger Index: The Challenge of Hunger: Ensuring Sustainable Food Security under Land, Water, and Energy Stresses. Retrieved from http://www.ifpri.org/sites/default/files/publications/ghi12.pdf 
Kannan, A. (2014). Food Sovereignty in the Era of Land Grabbing: An African Perspective. Journal of Sustainable Development, 7(2), 121-132. http://dx.doi.org/10.5539/jsd.v7n2p121

Miguel, A. (2009, July-August). Agroecology, Small Farms, and Food Sovereignty. Monthly Review, 61(3). http://monthlyreview.org/2009/07/01/agro eco logy-small-farms-and-food-sovereignty

Montpellier Panel. (2013). Sustainable Intensification: A New Paradigm for African Agriculture. London, England: Agriculture for Impact.

Moser, M. C., \& Barrett, B. C. (2003). The Disappointing Adoption Dynamics of a Yield-Increasing, Low External-Input Technology: The Case of SRI in Madagascar. Agricultural Systems, 76(3), 1085-1100. http://dx.doi.org/10.1016/S0308-521X(02)00041-0

Mueller, C. E., \& Gaus, H. (2014). Assessing the Performance of the "Counterfactual as Self-Estimated by Program Participants": Results from a Randomized Controlled Trial. American Journal of Evaluation (early view online). http://dx.doi.org/10.1177/1098214014538487

Mueller, C. E., Gaus, H., \& Rech, J. (2014). The Counterfactual Self-Estimation of Program Participants: Impact Assessment without Control Groups or Pretests. American Journal of Evaluation, 35(1), 8-25. http://dx.doi.org/10.1177/1098214013503182

Organization of Economic Corporation and Development (OECD). (2013). Promoting Sustainable Investments in Tanzania's agriculture. In OECD Investment Policy Reviews: Tanzania 2013 (pp. 211-306). OECD Publishing. http://dx.doi.org/10.1787/9789264204348-en

Pauw, K., \& Thurlow, J. (2011). Agricultural Growth, Poverty, and Nutrition in Tanzania. Food Policy, 36(6), 795-804._http://dx.doi.org/10.1016/j.foodpol.2011.09.002

Pretty, J., Camilla, T., \& Stella, W. (2011). Sustainable Intensification in African Agriculture. International Journal of Agricultural Sustainability, 9(1), 5-24. http://dx.doi.org/10.3763/ijas.2010.0583

Riddell, R. (2007). Does Foreign Aid Really Work? Oxford, England: Oxford University Press.

Riddell, R. (2013). Assessing the Overall Impact of Civil Society on Development at the Country Level: An Exploratory Approach. Development Policy Review, 31(4), 371-396. http://dx.doi.org/10.1111/dpr.12011

Silverman, D. (2013). Doing Qualitative Research: A Practical Guide (4th ed.). London, England: Sage Publications.

Stoop A. W. (2011). The Scientific Case for System of Rice Intensification and its Relevance for Sustainable Crop Intensification. International Journal of Agriculture Sustainability, 9(3), 443-455. http://dx.doi.org/10.1080/14735903.2011.583483

United Republic of Tanzania (URT). (2009). Ten Pillars of Kilimo Kwanza. Retrieved from http://www.tzonline.org/pdf/tenpillarsofkilimokwanza.pdf

United Republic of Tanzania (URT). (2011). Tanzania Agriculture and Food Security Investments Plan, 2011-12 to 2020-21. Retrieved from http://agrilinks.org/sites/default/files/resource/files/Tanzania\%20Second\%20Draft\%20Summary\%20TAFSI P.PDF

United States Government (USG). (2011). Tanzania Feed the Future Multi-Year Strategy. Retrieved from $\mathrm{http} / / /$ feedthefuture.gov/sites/default/files/country/strategies/files/TanzaniaFTFMulti-YearStrategy.pdf

World Bank. (2007). World Development Report 2008: Agriculture for Development. Washington, DC: World Bank. Retrieved from http://siteresources.worldbank.org/INTWDR2008/Resources/WDR_00_book.pdf

World Food Program (WFP). (2013). Comprehensive Food Security and Vulnerability Analysis: Tanzania 2012. Retrieved from http://documents.wfp.org/stellent/groups/public/documents/ena/wfp259829.pdf

\section{Copyrights}

Copyright for this article is retained by the author(s), with first publication rights granted to the journal.

This is an open-access article distributed under the terms and conditions of the Creative Commons Attribution license (http://creativecommons.org/licenses/by/3.0/). 